\title{
The Legal Anthropological Study of the Hungarian Roma Minority
}

\begin{abstract}
This article discusses the position of legal anthropology among the legal sciences and its interdisciplinary character through the example of the socio-legal studies of the Hungarian Roma minority. The first part illustrates the place of legal anthropology among the other legal and social disciplines, and its role in legal thinking, by the analysis of a practical question, "What can we do to improve the social position of the Hungarian Roma minority by legal means?" The second part considers the importance of legal anthropology in the Hungarian Roma studies, briefly sketching the characteristics of the ethnological, sociological and cultural anthropological approaches. Finally, the article surveys the insights gained from the socio-legal studies of the Hungarian Roma minority over the last two decades. It highlights the inspiring results of legal anthropological studies, and also the difficulties contemporary research has to face.
\end{abstract}

Keywords: legal anthropology, interdisciplinary research, Hungarian Roma minority

\section{The Interdisciplinary Character of Legal Anthropology}

I would like to begin with two preliminary remarks, one on the concept of legal anthropology and another on the nature of "legal thinking". Here, I understand legal anthropology as the study of the phenomena of social control in different societies (or social groups), largely by comparative and micro-sociological methods. ${ }^{1}$ The expression "phenomena of social control" leaves open the question of how we should conceptualize the phenomenon of law itself. It is especially important to emphasize that independently of how narrowly or broadly tailored a concept of law a given scholar actually uses in her study, the anthropological approach normally involves the study of a broadly conceived social and cultural context of the law. The adverb "largely" refers to the current tendencies in legal anthropology offering different theoretical and methodological frameworks than those of the classical sociological mainstream. We should mention the growing influence of postmodern philosophy manifesting itself, for instance, in the sophisticated methodology of "interpretive anthropology", ${ }^{2}$ or in the theoretical approach to the problem of legal pluralism, ${ }^{3}$ or in the

*Associate professor, Pázmány Péter Catholic University, Faculty of Law, H-1088 Budapest, Szentkirályi u. 28-30. Hungary.

E-mail: kopi@jak.ppke.hu

1 This definition is similar to what John Griffiths gave in his study "Recent Anthropology in the Netherlands and its Historical Background". In: Beckman, B.-von Beckman, K.-Strijbosh, F. (eds): Anthropology of Law in the Netherlands. Essays on Legal Pluralism. Dordrecht, 1986, 18-23.

2 See Geertz, C.: Fact and Law in Comparative Perspective. In: Geertz, C.: Local Knowledge. Further Essays in Interpretive Anthropology. New York, 1983, 167-234.

${ }^{3}$ See e.g. Sack, P.: Introduction. In: Sack, P.-Aleck, J. (eds.): Law and Anthropology, Aldershot, 1992. xiii-xxxi. Griffiths, J.: What Is Legal Pluralism? Journal of Legal Pluralism, 24 (1986) 1-55. Griffiths, J.: The Social Working of Legal Rules. Journal of Legal Pluralism, 48 (2003), 1-84. 
interpretation of legal rituals. ${ }^{4}$ Furthermore, we may also find other new approaches, which try to integrate, for example, the issues of socio-linguistics, ${ }^{5}$ or socio-biology ${ }^{6}$ into the anthropological studies.

In the course of the following argumentation, I will refer to "legal thinking" as a branch of practical philosophy-in an Aristotelian sense-, or as a form of prudentia (prudentia iuris)-in Aquinas' sense. ${ }^{7}$ By this definition I would like to emphasize that the legal problems par excellence are practical ones, thus legal knowledge is constantly organized around the question of "What to do?". We can contrast this with the question of "How does this work?" as a purely theoretical one, and we usually and traditionally-in the $19^{\text {th }}$-century sense-regard this kind of descriptive, theoretical knowledge as the proper body of scientific knowledge. The relation of these two different branches of knowledge is, of course, far more complex than this simple opposition and this is the special subject of epistemology. For instance, the question of "What to do?" generally involves, in fact, two questions: the question of aims and that of means. In answering these questions-and particularly the latter-, we often need theoretical knowledge, too, even if it is clear that we can never answer either of them relying on theoretical knowledge alone.

In the following I shall choose a particular legal question-"What can we do to improve the social position of the Hungarian Roma minority by legal means?"-and outline a sequence of problems which are all in relation with the efforts to find an answer (or answers) to that in order to demonstrate the inherent multidisciplinary nature of legal knowledge, and the interdisciplinary character of the branches of legal science.

As a first step, we can approach our question by investigating the current social position of the Hungarian Roma population. For this, sociological studies are needed to explore the different social aspects of their lives. And here, already at the first step of our investigation, comparison comes in, when we compare the Romas' social facts with the majority society's data to get a picture of their relative social advantages or disadvantages.

The next problem would be to find the causes of the Romas' disadvantaged social position. Here we can make good use of hints from history (e.g. about how the Romas came to Hungary, what their social position was in Hungarian society), political sociology (e.g. about the features of Hungarian society's social structure which may preclude the Romas' social integration), cultural anthropology (e.g. about the traditional culture, way of life and social structure of the Romas, which may make social integration into the majority society more difficult for them), and social psychology (e.g. about the Hungarian and Roma identities and their relations in the course of different social actions).

Then we need some knowledge about the available legal means. Firstly we have to know the Hungarian legal system, but not only the "positive law" but also its social effects. Thus, we cannot settle for the information provided by the different branches of positive law, but we have to call for the help of legal sociology (including criminology) and also

${ }^{4}$ See e.g. Schreiner, A. T. M.: Ritual and Law. International Congress of Law and Society, Glasgow, 1996, 10-13. Winn, P.: Legal Ritual. Law and Critique, 2 (1992), 207-232.

5 See e.g. O'Barr, W. M.-Conley, J. M.: Lay Expectation of the Civil Justice System. Law and Society, 22 (1981), 137-161; Mertz, E.: The Uses of History: Language, Ideology and Law in the United States and South Africa. Law and Society Review, 26 (1992) 2, 415.

${ }^{6}$ See e.g. Baerends, E. A.: The One-legged Chicken in the Shadow of Indebtedness. Groningen, 1994.

7 For the concept of practical philosophy see Agazzi, E.: Le bien, le mal et la science. Paris, 1996. 
legal anthropology (e.g. for investigating how their own social control of the different Roma groups work and are related to the state law). In this way, we can compare the manifest functions of the normative side of the legal system (intended by the lawmaker) with the latent functions of its (unintended) social effects.

Right before we start the moral, political and economic deliberation of the available legal means, we can take a look around to see how and by what legal means other countries have been handling the problems of the Roma social integration. At first sight, this task seems to be the proper field of comparative law. However, when we realize that, for instance, in France and Great Britain the Romas are defined by the law not as a national or ethnic minority but as a group of subjects who keep a special way of life, that is, they are traveling-voyagers, travelers-, then we have to acknowledge that the French and the British not only have "other" Romas (different from the Hungarian ones) but also different political and legal cultures in which those legal arrangements are working. And if we really want to understand how these legal arrangements are working-and what social effects they produce-, then we have to go well beyond the limits of comparative law, turning to cultural anthropology, political science and legal sociology for guidance.

Reviewing this outline, firstly, we should understand that-keeping in mind our preliminary definition about legal thinking-we can stamp the seal of "legal" on all of these stocks of knowledge drawn from different disciplines, since all of these were needed in resolving a legal question. The inherent multidisciplinary character of "legal thinking" becomes clear in the light of this insight.

Taking from the point of view of legal anthropology, the multidisciplinary nature of legal thinking evidently stimulates the unfolding of its interdisciplinary tendencies, and helps undo the borders among the modern social sciences, often built up by historical incidents. We can consider as such a historical co-incident, for instance, the historical context of colonization, resulting in the separation of sociology and social anthropology at the end of the $19^{\text {th }}$ century, or the theoretical differences among the national jurisprudential schools, leading to the division of legal anthropology and comparative law in the early $20^{\text {th }}$ century. Through its history of a hundred years-dating its birth to the year of the publishing of Bronislaw Malinowski's Crime and Custom in Savage Society-, legal anthropology has remained open towards the issues of the other disciplines sharing its methods or research subjects. Besides, it is still in a fruitful interaction with cultural anthropology, sociology, and social psychology, as well as with legal sociology, legal history, and comparative lawto mention but a few examples. In this interactive relationship, legal anthropology frequently offered itself as a field particularly suitable for integrating the insights of other disciplines and for making brand new revelations that give new impulses to further socio-legal studies.

\section{Hungarian Roma Studies}

Advancing chronologically, we should first mention ethnographic research, pointing out Kamill Erdős' works ${ }^{8}$ as of outstanding importance. Ethnographic studies, beginning in the first part of the $20^{\text {th }}$ century, have accumulated a great deal of empirical data but have given-because of some theoretical and methodological shortcomings-only a record of the cultural forms of the different Roma groups being in the "ethnographic present", and they

8 Vekerdi, J. (ed.): Erdős Kamill cigánykutatásai [Kamill Erdős’ Gypsy Studies]. Békéscsaba, 1989. 
have made a modest contribution to the better understanding of their way of life, structure, and relationships with the majority society.

Secondly, we should refer to the sociological studies started with the works of István Kemény and the members of the group that gathered around him at the beginning of the 1970s. ${ }^{9}$ The sociological approach deals with the Romas mainly from the perspective of the "Gypsy issue", keeping in sight of the unsolved problem of the Romas' integration into the majority society. For the sociologists, the "Gypsy issue" appears as a result of the Romas' social disadvantages and of the continuous "reproduction" of these conditions. Since the responsibility of solving these problems lies with the majority society, the sociologists' approach implies the perspective of the majority society, and it does not pay much attention to the Roma cultures, or, if it does, only as a factor responsible for the disadvantages.

The approach that appeared last, and is in fact still unfolding, is that of cultural anthropology. We may link its emergence to the publication of the Hungarian version of Michael S. Stuart's work, in which the author described the life of a Hungarian Vlach Roma community. ${ }^{10}$ Otherwise it was Csaba Prónai who has done the most for the introduction of cultural anthropology into Roma studies in Hungary. ${ }^{11}$ The anthropological perspective does not assume the point of view of an outsider, an allegedly unbiased observer, or that of the majority society, but that of the Romas themselves. Anthropologists are trying to understand Roma cultures from "inside", and to explain this way how these cultures function and contribute to the maintenance of their social structure - including their relationships with the majority society.

To be sure, these approaches can be clear-cut only if we take them as "ideal types". Indeed, it can be seen that a lot of efforts have been made in the fast growing literature of the last fifteen years, and mainly in the works of younger researchers, to integrate the different approaches. The issues and methods of socio-linguistics and social psychology are gaining importance in the study of socialization, identity-formation, and linguistic pragmatics.

\section{Legal Anthropological Studies}

Legal anthropology appeared on the horizon of Hungarian jurisprudence only more than sixty years after Malinowski's above mentioned work: In an article published in the mid1980s, Csaba Varga discussed Leopold Pospíšil's anthropological theory of law. ${ }^{12}$ The comprehensive reception of the issues and main currents of the discipline did not take place before the 1990s-due to the desperate resistance of "socialist jurisprudence". ${ }^{13}$ This reception resulted in a textbook giving an overview of the forming and development of

9 Kemény, I.-Janky, B.-Lengyel, G.: A magyarországi cigányság, 1971-2003 [The Hungarian Gypsies, 1971-2003]. Budapest, 2004.

10 Stewart, M. S.: Daltestvérek. A cigány identitás és közösség továbbélése a szocialista Magyarországon [Brothers in Song. The Persistence of Gypsy Identity and Community in Socialist Hungary]. Budapest, 1994.

11 Prónai, Cs.: Cigánykutatás és kulturális antropológia [Gypsy Studies and Cultural Anthropology]. Budapest, 1995.

12 Varga, Cs.: Anthropological Jurisprudence? Budapest, 1986.

13 See H. Szilágyi, I.: Let Us Invent Hungarian Legal Anthropology. Rechtstheorie, 33 (2002), 187-196. 
legal anthropology and of its theoretical and methodological issues. ${ }^{14}$ In the same year, a reader was published, which contained, in chronological order, a selection of writings from Malinowski, Isaac Schapera, Karl N. Llewellyn, Leopold Pospíšil, Paul Bohannan, Sally Falk Moore, Philip Huge Gulliver, Jane F. Collier, Laura Nader, and John Griffiths, among others. ${ }^{15}$ The introduction of the discipline in legal education also started in the mid-1990s, first at the law faculty of the University of Miskolc, then at Pázmány Péter Catholic University.

The Roma minority evidently offered itself as a research subject for the emerging empirical studies at the end of the 90s not only because of the political actualities of the "Gypsy-issue", ${ }^{16}$ but also because the theoretical and methodological advantages of the anthropological approach in this field were obvious, if compared to those of classical legal sociology.

Chronologically, the first research study was carried out between 1997 and 1999 at a local court (of first instance) in county Borsod-Abaúj-Zemplén (in the Northwestern region of Hungary). Originally, the study was designed to examine the question whether or not Romas have certain cultural patterns which might influence their relationship to the law. The question was inspired by the contradiction between findings formulated in Hungarian criminological literature concerning the so-called "Gypsy crime", and those of contemporary legal anthropology and comparative law. According to the former, the "Gypsy crime", i.e. the fact that Romas are over-represented among the perpetrators of certain types of crime, is basically a sociological problem, rooted in the poverty and lack of education of the Hungarian Roma minority, because the part of the non-Roma population that is characterized by the same "hard facts" has the same criminality rate. The anthropological and comparative approach, on the other hand, emphasizes the importance of Roma culture in the Romas' relation to the law. The researchers carrying out the study adapted this latter perspective, which influenced both the choice of setting and method of research.

According to the first conception, the research study would have been conducted at a court of first instance, investigating the court proceedings in civil law cases and applying the method of participating observation. The researchers would have compared the records of cases in which either the plaintiffs or the defendants were Romas with those of a nonRoma control group, aiming to draw conclusions about Roma cultural patterns. The supposition behind this first conception was that the eventual distorting effect of prejudice against the Romas, which is prevalent among the Hungarian majority and it even appears in the affairs of the police and other state organs, on the court would be the least present in civil law cases, in which the initiative of the procedural acts would have belonged to the parties.

However, the errors of this conception became obvious towards the end of the first year of the study. First it turned out, as others had already observed, that there were practically a negligible number of Roma clients appearing in civil law cases, that is to say, Romas are heavily under-represented in civil law cases. Secondly, the researchers had to face the realization that their efforts to exclude the effects of discriminative prejudice are

${ }^{14}$ H. Szilágyi, I.: A jogi antropológia föbb irányai [Main Trends in Legal Anthropology]. Budapest, 2000.

15 H. Szilágyi, I.: Jog és antropológia [Law and Anthropology]. Budapest, 2000.

${ }^{16}$ Cf. H. Szilágyi, I.-Loss, S.: Opening Scissors: The Legal Status of the Gypsy Minority in the Nowadays Hungary. Rechtstheorie, 33 (2002), 483-494. 
futile and mistaken. They concluded that they must take into account the entire process of interaction that takes place in the courtroom, as well as expand the scope of the research to include criminal cases. The value judgments, prejudices, and attitudes of non-Roma participants will necessarily be present in the totality of the interaction in the courtroom proceedings, alongside the patterns of Roma culture-if these exist at all-that influence the behavior of Roma parties, mostly defendants in criminal cases. This conclusion has led to the re-formulation of the basic research question, and to the introduction of the concept of "Gypsy trial" which exhibits different features as compared to trials with non-Roma parties (defendants).

At the same time, the researchers opted to keep the method of participating observation, which is not so much descriptive, but conveys the opinion of the actors, as it appeared to be more effective in the study of courtroom communication than the questionnaire method. The development of the system of criteria to be applied in the observation, the training of "field workers" (third year law students and students of cultural and visual anthropology at the University of Miskolc in 1997-98) and their introduction to the court have all been accomplished by the end of the first year. In the next year and a half they collected information for about fifty case studies of court proceedings. They tried to make "thick descriptions" and accurately record the behavior of the persons involved in the proceedingstheir appearance, clothes, gestures, linguistic abilities, emotional depth, etc.

The researchers concluded from the results of the study that the essence of the "Gypsy trial" is ritualized jurisdiction: the "Gypsy trial" is not a trial but a rite. The rite is a formalized sequence of acts that has no inherent meaning. More closely, in terms of the "Gypsy trial" this statement means that there is no legal dispute running in the formal structure of the court proceedings. The fact that rite has no inherent meaning does not preclude that it can serve some kind of a social function. According to the researchers, this function in case of the "Gypsy trial" becomes the maintenance of a system of mutual prejudices between the majority and the Roma minority, in a way that it becomes contributory to the segregation of the latter. ${ }^{17}$

The second research was based on six months of fieldwork which began in the autumn of 2000. The protagonists of this study were the members of a scavenging Roma family, who lived in an industrial city in North-eastern Hungary. ${ }^{18}$ The immediate objective of the research study was not a legal anthropological one-even though it involved interesting legal aspects-, but to study the way of life of three members of the family. The theoretical background for this comprised three major components. One was the fact that the researchers relied on the classical sociological tradition when defining the concept of lifestyle, according to which they divided the life of this family into different dimensions and aspects: living environment, subsistence, relations to work, state of health, patterns of hygiene and alcohol-consumption. Second, when analyzing the relationship between this micro-environment and the broader social setting, with special regard to the police and other state institutions, the researchers made use of the concepts and findings of legal anthropology, in particular those concerning semi-autonomous social fields. Finally, the researchers relied on the recent literature emerging from the anthropological study of

${ }^{17}$ For the final report of the research see H. Szilágyi, I.-Loss, S.: A cigány per [The Gipsy Trial]. Beszélö, 6 (2001) 4, 94-100.

18 For the detailed version of the final report see Csajbók, A.-Kelemen, E.-H. Szilágyi, I.Baksa, A.: Among Roma. Miskolc, 2002. 
traditional Roma communities, discussing issues of subsistence, identity and marginality. Participating observation played a decisive role in collecting data in this research study as well, and was performed by two highly skilled anthropologists with an accuracy meeting classical standards, and it even included common pubbing and participation in scavenging.

As for the legal aspects of the research, they appeared in the analysis of the relations of the family to the police. The researchers drew the conclusion that among the institutions of the majority society the family had the closest relationship to the police despite the fact that they were not criminals.

If we had to summarize the lessons of the two studies, we could say that Romas really are different. They behave differently in the courtroom than non-Roma people; homeless scavenging Romas who live in the countryside are really different from the non-Roma homeless scavengers living in the big cities. At this point, however, the majority society and its institutions are incapable of doing anything else about this "otherness" than stigmatizing and rejecting it. If we want to change the latter (the stigmatization and rejection of the Roma minority by the majority) then we have to understand the former (the Romas' "otherness"). ${ }^{19}$

Let us now take a look at the effects of these two researches on Roma studies which were unfolding in two ways, and Sándor Loss' work played a key role in both of them. As we have pointed out earlier, one of the results of the first research was the realization of the fact that the Romas were significantly under-represented in civil law cases. At that time, the hypothesis was formulated that the explanation of this fact could be that Roma communities were capable to handle this kind of conflicts on their own. This assumption, however, contradicted the contemporary views of legal sociology and ethnography, which held that the "Gypsy court" (Romani kris) existed only in the time of the "ethnographic present" (around 1870-1940), and it withered away by the process of modernization in the socialist era at the latest. Sándor Loss clarified by half a year of fieldwork in 2001 that the Romani kris still survived and functioned nearly in its traditional form within a Mašari (a Vlach Roma kinship) community in county Békés. ${ }^{20}$

The other research topic flowing from the previous anthropological studies was the investigation of the Hungarian judicial system's discriminative tendencies. A research project was conducted by the Hungarian Helsinki Committee between 2001-2004, analyzing the material of 1147 first instance court decisions. ${ }^{21}$ The research did not support beyond doubt that the courts' decision-making would be discriminative, in terms of the weight of the sanctions imposed or any other important aspect, but it called attention to the

19 For a semiotic analisys of the outcomes of the two researches see H. Szilágyi, I.: The Roma Way. In: Wagner, A.-Bhatia, V. K. (eds): Diversity and Tolerance in Socio Legal Context: Explorations in the Semiotics of Law. Aldershot, 2009, 65-80.

${ }^{20}$ Loss, S.: Romani kris a dél-békési oláhcigányoknál. Elmélet és gyakorlat [The Romani Kris by the Vlach Gipsys of South Békés. Theory and Practice]. In: Szabó, M. (ed.): Ius Humanum. Miskolc, 2001, 9-22.

${ }^{21}$ About the methodology of the research project see Loss, S.: A törvény elötti egyenlőség elvének érvényesülése a büntetőeljárásban cigány és nem cigány terheltek esetén [The realisation of the equality principle in the criminal process in the case of Gypsy and non-Gypsy defendants]. In: Szabadfalvi, J. (ed.): Facultas nascitur. Miskolc, 2001, 283-307. 
discrimination present in the police work, which induced further criminological studies on the problem of racial profiling. ${ }^{22}$

A certain decline of the legal anthropological studies of the Roma minority can be observed in the last half decade. (The present author regards as a turning point 2004, the year of Sándor Loss' untimely death who was an excellent field worker and research organizer in one person.) The most important causes of this decline can be enumerated as follows:

First, neither cultural anthropology, nor legal anthropology could firmly institutionalize itself in the Hungarian academic structure. This is partly due to the resistance of the inveterate academic structure, partly to the recent decrease in the general reputation of the humanities. Second, also legal education has been transformed, with the theoretical subjects thrust into the background of an increasingly practice-oriented curriculum. Third, empirical studies lost their popularity even among young researchers, who are now interested in theoretical problems: it seems to be a more attractive task for them to deal with books than with, say, real-life Roma people.

There are, of course, other, more general social conditions beyond these factors. We may mention, for instance, that the newly formed Hungarian political elite have gradually lost its interest in social reality, and is occupying itself by building of his own political vision. This leads directly to the disregard of empirical social studies within science policy. Finally, a further obstacle in the way of Roma studies is that the frustration-aggression circle has been resumed in Hungarian society over the last years of economic depression, which is inflicting the victimization of Roma people-just as it happened in the years after 1989.

In the opinion of the present author, a good panacea for this current crisis can be found in the more active engagement of Hungarian researchers in the international network of legal anthropological studies.

22 See Farkas, L.-Kézdi, G.-Loss, S.-Zádori, Zs.: A rendőrségi profilalkotás mai gyakorlata [Today's Practice of the Police in Racial Profiling]. www.oji.u-szeged.hu/kontroll/pdf/Kontroll4eng. pdf [2004]. 